\title{
The Oxidative Stress of Hyperhomocysteinemia Results from Reduced Bioavailability of Sulfur-Containing Reductants
}

\author{
Yves Ingenbleek*
}

Laboratory of Nutrition, Faculty of Pharmacy, University Louis Pasteur Strasbourg, France

\begin{abstract}
Vegetarian subjects consuming subnormal amounts of methionine (Met) are characterized by subclinical protein malnutrition causing reduction in size of their lean body mass (LBM) best identified by the serial measurement of plasma transthyretin (TTR). As a result, the transsulfuration pathway is depressed at cystathionine- $\beta$-synthase (C $\beta S$ ) level triggering the upstream sequestration of homocysteine (Hcy) in biological fluids and promoting its conversion to Met. Maintenance of beneficial Met homeostasis is counterpoised by the drop of cysteine (Cys) and glutathione (GSH) values downstream to $\mathrm{C} \beta \mathrm{S}$ causing in turn declining generation of hydrogen sulfide $\left(\mathrm{H}_{2} \mathrm{~S}\right)$ from enzymatic sources. The biogenesis of $\mathrm{H}_{2} \mathrm{~S}$ via non-enzymatic reduction is further inhibited in areas where earth's crust is depleted in elemental sulfur $\left(\mathrm{S}_{8}\right)$ and sulfate oxyanions. Combination of subclinical malnutrition and $\mathrm{S}_{8}$-deficiency thus maximizes the defective production of Cys, GSH and $\mathrm{H}_{2} \mathrm{~S}$ reductants, explaining persistence of unabated oxidative burden. The clinical entity increases the risk of developing cardiovascular diseases (CVD) and stroke in underprivileged plant-eating populations regardless of Framingham criteria and vitamin-B status. Although unrecognized up to now, the nutritional disorder is one of the commonest worldwide, reaching top prevalence in populated regions of Southeastern Asia. Increased risk of hyperhomocysteinemia and oxidative stress may also affect individuals suffering from intestinal malabsorption or westernized communities having adopted vegan dietary lifestyles.
\end{abstract}

Keywords: Vegetarianism, malnutrition, sulfur-deficiency, hyperhomocysteinemia, oxidative stress, hydrogen sulfide, cardiovascular diseases, developing countries, Asia.

Homocysteine (Hcy) is a nonproteogenic sulfurcontaining amino acid (SAA) generated by the intrahepatic transmethylation (TM) of dietary Met. Hcy may either be recycled to Met following remethylation (RM) pathways or catabolized along the transsulfuration (TS) cascade. Under normal circumstances, the Met-Hcy cycle stands under the regulatory control of three watersoluble B-vitamins: folates (5-methyl-tetrahydrofolates, $\mathrm{B}_{9}$ ) are regarded as the main factor working as donor of the $\mathrm{CH}_{3}$ group involved in the remethylation process, pyridoxine (pyridoxal-5'-phosphate, PLP, $B_{6}$ ) plays the role of co-factor of both cystathionase enzymes belonging to the TS pathway and cobalamins $\left(\mathrm{B}_{12}\right)$ ensure that of methionine-synthase. The main steps of the Met $\rightarrow$ Hcy $\rightarrow$ Met cycle are summarized in Fig. (1).

Hyperhomocysteinemia (HHcy) is an acquired metabolic anomaly first identified by McCully [1], a finding confirmed in the last four decades by a considerable body of experimental and clinical investigations. The current consensus is that dietary deficiency in any of three watersoluble vitamins may operate as causal factor of HHcy. PLP-deficiency may trigger the upstream accumulation of Hcy in biological fluids [2] whereas the shortage of vitamins $B_{9}$ or $B_{12}$ is held responsible for its downstream sequestration [3,4]. HHcy is regarded as a major causal determinant of CVD working as

*Address correspondence to this author at the Laboratory of Nutrition, Faculty of Pharmacy, University Louis Pasteur Strasbourg, France; Tel: 00-334677487 17; E-mail: ingen@unistra.fr an independent and graded risk factor unrelated to the classical Framingham criteria such as hypercholesterolemia, dyslipidemia, sedentary lifestyle, diabetes and smoking. Hcy may invade the intracellular space of many tissues and locally generate in a time- and concentration-dependent manner [5] endothelial dysfunction working as early harbinger of blood vessel injuries and atherosclerosis. Although many deleterious mechanisms have been incriminated [6], most investigators contend the view that production of harmful reactive oxygen and nitrogen species (ROS, NOS), notably hydrogen peroxide $\left(\mathrm{H}_{2} \mathrm{O}_{2}\right)$, superoxide anion $\left(\mathrm{O}_{2}{ }^{-{ }^{-}}\right)$and peroxinitrite $\left(\mathrm{ONOO}^{-}\right)$, constitutes a major culprit in the development of HHcy-induced vascular damages [7-10]. Accumulation of ROS is associated with increased risk for cardiovascular diseases [11] and stroke [12], arterial hypertension [6], kidney dysfunction [13], Alzheimer's disease [14], cognitive deterioration [15], inflammatory bowel disease [16] and bone remodeling [17].

We nevertheless observe that these toxicological effects currently overlook the potential protective roles played by extra- and intracellular reductants such as cysteine (Cys) and glutathione $(\mathrm{GSH})$ in the sequence of events leading from HHcy to tissular damages. Moreover, after the discovery of nitric oxide (NO) and carbon oxide (CO), hydrogen sulfide $\left(\mathrm{H}_{2} \mathrm{~S}\right)$ is the third gaseous signaling messenger found in mammalian tissues [18]. $\mathrm{H}_{2} \mathrm{~S}$ is a reducing molecule displaying strong scavenging properties as animal experiments and tissue cultures demonstrate that exogenous supply of the gasotransmitter significantly attenuates [19, 20] or even 


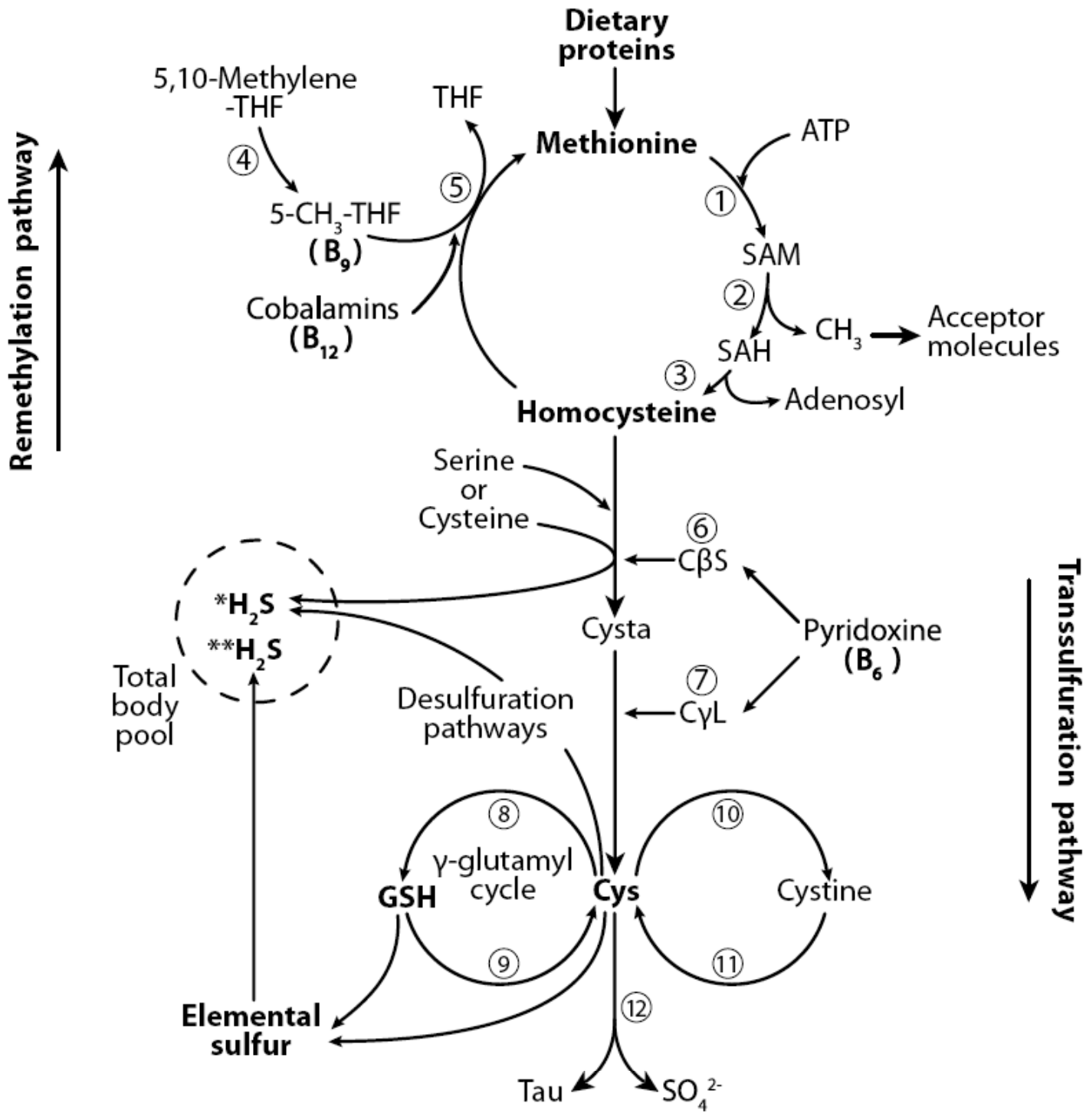

Fig. (1). Schematic representation of the methionine cycle and homocysteine degradation pathways.

Compounds: ATP, adenosyltriphosphate; THF, tetrahydrofolate; SAM, S- adenosylmethionine; SAH, adenosylhomocysteine; Cysta, cystathionine; Cys, cysteine; GSH, glutathione; $\mathrm{H}_{2} \mathrm{~S}$, hydrogen sulfide; Tau, taurine; $\mathrm{SO}_{4}{ }^{2-}$, sulfate oxyanions.

Enzymes: (1) Met-adenosyltransferase; (2) SAM-methyltransferases; (3) adenosyl-homocysteinase; (4) methylene-THF reductase; (5) Metsynthase; (6) cystathionine- $\beta$-synthase, C $\beta S$; (7) cystathionine- $\gamma$-lyase, $\mathrm{C} \gamma \mathrm{L}$; (8) $\gamma$-glutamyl-synthase; (9) $\gamma$-glutamyl-transpeptidase; (10) oxidase; (11) reductase; (12) cysteine-dioxygenase, CDO.

Metabolic pathways: Met molecules supplied by dietary proteins are submitted to TM processes allowing to release Hcy which may in turn either undergo Hcy $\rightarrow$ Met RM pathways or be irreversibly committed into TS decay. Impairment of C $\beta S$ activity, as described in protein malnutrition, entails supranormal accumulation of Hcy in body fluids, stimulation of (5) activity and maintenance of Met homeostasis. This last beneficial effect is counteracted by decreased concentration of most components generated downstream to C $\beta S$, explaining the depressed C $\beta S$ - and $\mathrm{C} \gamma \mathrm{L}$-mediated enzymatic production of ${ }^{*} \mathrm{H}_{2} \mathrm{~S}$ along the TS cascade. The restricted dietary intake of elemental $\mathrm{S}$ further operates as a limiting factor for its non-enzymatic reduction to $* * \mathrm{H}_{2} \mathrm{~S}$ which contributes to downsizing a common body pool (dotted circle). The data show that combined protein- and S-deficiencies work in concert to deplete Cys, GSH and $\mathrm{H}_{2} \mathrm{~S}$ from their body reserves, hence impeding these reducing molecules to properly face the oxidative stress imposed by hyperhomocysteinemia.

abolishes [21,22] the oxidative injury imposed by HHcy burden. The endogenous production of the naturally occurring $\mathrm{H}_{2} \mathrm{~S}$ reductant depends on Cys bioavailability through the mediation of TS enzymes [23,24]. Production of $\mathrm{H}_{2} \mathrm{~S}$ may also occur in human tissues starting from elemental sulfur, a non-enzymatic reaction requiring the presence of Cys, GSH, and glucose $[25,26]$. It would be worth disentangling the respective roles played by Cys, GSH and $\mathrm{H}_{2} \mathrm{~S}$ for the prevention and restoration of HHcy-induced oxidative lesions. This proposal is made in the light of a recently published study showing that the plasma concentration of Cys and GSH is severely depressed in subclinically malnourished HHcy patients [27], hence impeding appropriate biogenesis of $\mathrm{H}_{2} \mathrm{~S}$ molecules. The present paper attempts to clarify the biological consequences resulting from the complex interplay existing between the 3 reducing molecules, allowing to 
throw deeper insight into the pathophysiologic mechanisms associated with HHcy states.

\section{CLINICAL BACKGROUND}

Numerous surveys undertaken throughout the last decades have conclusively shown that the watersoluble vitamin deficiency concept, taken together, provides only partial causal account of the HHcy metabolic anomaly. In contrast, recent studies have highlighted that the components of body composition, mainly the size of lean body mass (LBM), constitutes a critical determinant of HHcy status [28,29]. Because nitrogen $(\mathrm{N})$ and sulfur $(\mathrm{S})$ concentrations maintain tightly correlated ratios in tissues of both healthy subjects [30] and diseased patients [31], it might follow that defective $\mathrm{N}$ intake and accretion rate would cause concomitant and proportionate depletion of total body $\mathrm{N}(\mathrm{TBN})$ and total body S (TBS) stores [30]. Our clinical investigation undertaken in Central Africa in apparently healthy but nevertheless subclinically malnourished vegetarian subjects has documented that reduced size of LBM could lead to HHcy states [27].

The field study was conducted in the southern part of the Republic of Chad, a sahelian area mainly populated with inhabitants belonging to the Sara ethnic group [27]. In this semi-arid region, the staple food is monotonous, consisting mainly of cassava, sweet potatoes, beans, millets and groundnuts. Participants were invited to fill in a detailed dietary questionnaire whose results were compared with values reported in food composition tables [32-34] allowing to calculate the proportion of energy, fiber, carbohydrate, lipid, protein, and SAAs ingested on a daily basis [27]. Overall health status was determined as well as plasma lipids, watersoluble vitamins and selected CVD risk factors. The dietary inquiry indicates that participants consumed a significantly lower mean SAA intake $\left(10.4 \mathrm{mg} \cdot \mathrm{kg}^{-1} \cdot \mathrm{d}^{-1}\right)$ [27] than the Recommended Dietary Allowances (RDAs) (13 mg.kg $\left.{ }^{-1} \cdot \mathrm{d}^{-1}\right)$ $[33,34]$.

The blood lipid profiles of rural subjects were confined within normal ranges ruling out this class of parameters as causal risk factors for CVD disorders. The normal levels measured for pyridoxine, folates, and cobalamins did preclude these vitamins from playing any significant role in the rise of Hcy plasma concentrations [27]. Analysis of plasma SAAs revealed unmodified methioninemia, significantly elevated Hcy values $(18.6 \mu \mathrm{mol} / \mathrm{L})$ contrasting with significantly decreased plasma Cys and GSH values [27]. The significant lowering of classical anthropometric parameters (body weight, BW; body mass index, BMI) together with that of the main plasma and urinary biomarkers of metabolic (visceral) and structural (muscular) compartments point to an estimated $10 \%$ shrinking of LBM [27]. We have attached peculiar importance to the measurement of plasma transthyretin (TTR) since this indicator integrates the evolutionary trends outlined by body protein reserves [35], providing from birth until death an overall and balanced estimate of LBM fluctuations [29]. In the absence of any superimposed inflammatory condition, LBM and TTR profiles indeed reveal striking similarities [29]. Scientists belonging to the Foundation for Blood Research (Scarborough, Maine, 04074, USA) have recently published a large number of TTR results recorded in 68,720 healthy US citizens aged 0-100 yr which constitute a comprehensive reference material to follow the shape of LBM fluctuations in relation with sex and age [29]. TTR concentrations plotted against Hcy values reveal a strongly negative correlation $(\mathrm{r}=-0.71)$ already described previously [29,30], confirming that the depletion of TBN and TBS stores plays a predominant role in the development of HHcy states. The body of a reference man weighing $70 \mathrm{~kg}$ contains $64 \mathrm{M}$ of $\mathrm{N}(1,800 \mathrm{~g})$ and 4,400 mM of S (140 g) [36].

Our vegetarian subjects consume diets providing low fat and high fiber content conferring a large spectrum of welldescribed health benefits notably for the prevention of several chronic disorders such as cancer and diabetes, together with an effective protection against the risk of hypercholesterolemia-induced CVD $[37,38]$. Plant-based regimens, however, do not supply appropriate amounts of nitrogenous substrates of good biological value which are required to adequately fulfill mammalian tissue needs [30]. More precisely, vegetable items contain suboptimal concentrations of both SAAs [33,34,39] below the customary RDA guidelines. This dietary handicap may be further deteriorated by unsuitable food processing [40] and by the presence in plant products of naturally occurring anti-nutritional factors such as tannins in cereal grains and anti-trypsin or anti-chymotrypsin inhibitors in soybeans and kidney beans [41].

\section{IMPAIRMENT OF THE TRANSSULFURATION PATHWAY}

The hypothesis that subclinical protein malnutrition might be involved in the occurrence of HHcy states via inhibition of cystathionine- $\beta$-synthase $(\mathrm{C} \beta \mathrm{S})$ activity did first arise in Senegal in 1986 [42] and was later corroborated in Central Africa [43]. The concept was clearly counterintuitive in that it was unexpected that high Hcy plasma values might result from low intake of its precursor Met molecule. Despite the low SAA intake of our vegetarian patients [27], plasma Met concentrations disclosed noticeable stability allowing to maintain the synthesis and functioning of myriads of Metdependent molecular, structural and metabolic compounds described in detail elsewhere $[30,44]$. These clinical investigations have received strong support from recent mouse [45] and rat [46] experiments submitted to Met-restricted regimens. At the end of the Met-deprivation period, both animal species did manifest meaningful HHcy states $(\mathrm{p}<0.001)$ contrasting with significantly lower BW $(\mathrm{p}<0.001)$ reduced by $33 \%$ [45] and $44 \%$ [46] of control, respectively. In comparison with all other indispensable AAs, the uniqueness of Met behavior stands in accordance with balance studies performed on large mammalian species showing that the complete withdrawal of Met from otherwise normal diets causes the greatest rate of body loss, nearly equal to that generated by protein-free regimens $[47,48]$.

This efficient Met homeostatic mechanism is classically ascribed to a PLP-like inhibition of C $\beta S$ activity exerted through allosteric binding of S-adenosylmethionine (SAM) to the C-terminal regulatory domain of the enzyme $[49,50]$. The validity of such allosteric mechanism has been recently questioned, at least in Met-depleted animal studies, showing that the loss of C $\beta S$ activity may develop via a (post)translational defect independently from intrahepatic SAM concentrations [45]. We have postulated the existence 
of an independent sensor mechanism set in motion by TBS pool shrinkage and reduced bioavailability of Met - its main building block - working as an inhibitory feedback loop of C $\beta S$ activity [30]. Such Met-bodystat, likely to be centrallymediated, and aiming at maintaining unaltered Met disposal in conditions of decreased dietary provision implies the fulfillment of high metabolic priorities of survival value $[30,44]$.

Whereas HHcy may be regarded as the dark side of a beneficial adaptive machinery [43], impairment of the TS pathway also depresses the production of compounds situated downstream to the C $\beta S$ blockade level, notably Cys and $\mathrm{GSH}$, keeping in mind that Cys may undergo reversible GSH conversion (Fig. 1). The plasma concentration of both Cys and GSH reductants is indeed significantly decreased in our vegetarian subjects by $33 \%$ and $67 \%$ of control, displaying negative correlations ( $\mathrm{r}=-0.67$ and -0.37 , respectively) with HHcy values [27]. Reduced dietary intake of the preformed Cys molecule [27] and diminished Cys release from protein breakdown in malnourished states [51] may contribute to the lowering effect. The significantly decreased GSH blood levels may similarly be attributed to dietary composition since the tripeptide is mainly found in meat products but is virtually absent from cereals, roots, milk and dairy items [52] and because regimens lacking SAAs may lessen the production of blood GSH and its intrahepatic sequestration [53].

\section{BIOGENESIS OF HYDROGEN SULFIDE}

The TS degradation pathway schematically proceeds along two main PLP-dependent enzymatic reactions working in succession (Fig. 1). The first is catalyzed by C $\beta S$ (EC 4.2.1.22) governing the $\beta$-replacement of the hydroxyl group of serine with Hcy to generate Cysta plus $\mathrm{H}_{2} \mathrm{O}$. Cys may however substitute for serine and the $\beta$-replacement of its sulfhydryl group with Hcy releases Cysta and $\mathrm{H}_{2} \mathrm{~S}$ instead of water [54]. The second is regulated by cystathionine- $\gamma$-lyase (C $\gamma \mathrm{L}, \mathrm{EC}$ 4.4.1.1.) hydrolyzing Cysta to release Cys and $\alpha-$ ketobutyrate plus ammonia as side-products [55]. Under the control of $\mathrm{C} \beta \mathrm{S}$ or $\mathrm{C} \gamma \mathrm{L}$ enzymes, Cys may also undergo nonoxidative desulfuration pathways leading to $\mathrm{H}_{2} \mathrm{~S}$ or sulfanesulfur production [56]. Alternatively, Cys may be committed into oxidative conversion regulated by cysteine-dioxygenase (CDO, EC 1.13.11.20) which catalyzes the replacement of the $\mathrm{SH}^{-}$group of Cys by $\mathrm{SO}_{3}{ }^{-}$to yield cysteine-sulfinate [56]. This last compound may be further decarboxylated to hypotaurine that is finally oxidized to $\mathrm{Tau}(67 \%)$ and $\mathrm{SO}_{4}{ }^{2-}$ oxyanions (33\%) [56]. C $\beta S$ and $C \gamma L$ are both cytosolic enzymes and their relative contribution to the generation of $\mathrm{H}_{2} \mathrm{~S}$ may vary according to animal strains, tissue specificities and nutritional or physiopathological circumstances [23,24]. $\mathrm{C} \beta \mathrm{S}$ and $\mathrm{C} \gamma \mathrm{L}$ are expressed in most organs such as liver, kidneys, brain, heart, large vessels, ileum and pancreas $[57,58]$ potentially subjected to HHcy-induced ROS injury while keeping the capacity to desulfurate Cys and to locally produce $\mathrm{H}_{2} \mathrm{~S}$ as cytoprotectant signaling agent. C $\beta \mathrm{S}$ is the principal TS enzyme found in cerebral glial cells and astrocytes [59]. C $\gamma \mathrm{L}$ predominates in the vascular system [60] whereas both enzymes are present in the renal proximal tubules [61].

$\mathrm{H}_{2} \mathrm{~S}$ is the third gaseous substrate found in the biosphere [18] after NO and CO. All three gases are characterized by severe toxicity when inhaled at high concentrations. In particular, $\mathrm{H}_{2} \mathrm{~S}$ produced by anaerobic fermentation is capable of causing respiratory death by inhibition of mitochondrial cytochrome $\mathrm{C}$ oxidase [62]. $\mathrm{NO}, \mathrm{CO}$ and $\mathrm{H}_{2} \mathrm{~S}$ are synthesized from arginine, glycine and Cys, respectively, exerting at low concentrations major biological functions in living organisms. Most of our knowledge on these atypical signal messengers [63] are derived from animal experiments and tissue cultures. These transmitter molecules may share some properties in common such as penetration of cellular membranes independently from specific receptors [64]. They are also manifesting dissimilar activities: whereas $\mathrm{NO}$ and $\mathrm{CO}$ activate guanylyl cyclase to generate biological responses via cGMP-dependent kinases, $\mathrm{H}_{2} \mathrm{~S}$ induces $\mathrm{Ca}^{2+}$-dependent effects through ATP-sensitive $\mathrm{K}^{+}$channels [65]. Some of these potentialities may work in concert while others operate antagonistically. For instance, $\mathrm{NO}$ and $\mathrm{H}_{2} \mathrm{~S}$ express vasorelaxant tone on endogenous smooth muscle [66] but reveal different effects on large artery vessels [67]. The data suggest that these gaseous substances maintain whole body homeostasis through complex interactions and multifaceted crosstalks between signaling pathways.

Elemental S (32.064 as atomic mass) is a primordial constituent of lava flows in areas of volcanic or sedimental origin usually presenting as crown-shaped stable octamolecules - hence its $\mathrm{S}_{8}$ symbolic denomination - which may conglomerate to form brimstone rocks. The vegetable kingdom is unable to assimilate $S_{8}$ and requires as prior step its natural or bacterial oxidation to $\mathrm{SO}_{4}{ }^{2-}$ derivatives before launching the synthesis of SAA molecules along narrowly regulated metabolic pathways [30,44]. Distinct anabolic processes are identified in mammalian tissues which lack the enzymatic equipment required to organize sulfate oxyanions but possess the capacity of direct $\mathrm{S}_{8}$ conversion into $\mathrm{H}_{2} \mathrm{~S}$. $\mathrm{S}_{8}$ is poorly soluble in tap waters [68] may be taken up and transported to mammalian tissues loosely fastened to serumalbumin (SA) [69]. S may also be covalently bound to intracellular S-atoms taking the form of sulfane-sulfur compounds [70] either firmly attached to cytosolic organelles or in untied form to mitochondria $[57,58,71,72]$ to undergo later release in response to specific endogenous requirements [71]. Sulfane-sulfur compounds are somewhat unstable and may decompose in the presence of reducing agents allowing the restitution of $S[70,71]$. $S$ may either endorse the role of stimulatory factor of several mammalian apoenzyme activities as shown for succinic dehydrogenase [73] and NADHdehydrogenase [74] or operate as inhibitory agent of other mammalian apoenzymes such as adenylate kinase [75] and liver tyrosine aminotransferase [76]. Elemental $\mathrm{S}$ resulting from dietary supply or from sulfane-sulfur decay may be subjected to non-enzymatic reduction in the presence of Cys and GSH [25,26] and/or reducing equivalents obtained from glucose oxidation [25], hence yielding at physiological $\mathrm{pH}$ additional provision of $\mathrm{H}_{2} \mathrm{~S}$.

The gaseous mediator is a weakly acidic molecule endowed with strong lipophilic affinities. In experimental models, the blockade of the TS cascade at C $\beta S$ or $C \gamma L$ levels significantly depresses or even abolishes the vitally required production of Cys operating at the crossroad of multiple converting processes (Fig. 1). Addition of Cys to the incubation milieu resumes the generation of $\mathrm{H}_{2} \mathrm{~S}$ [19] in a Cys concentration-dependent manner [77]. The data indicate that, in 
the context of SAA deprivation, the compounds situated downstream both cystathionases keep their functional potentialities but are unable to express their converting Cys $\rightarrow$ $\mathrm{H}_{2} \mathrm{~S}$ capacities in the absence of precursor substrate. Summing up, inhibition of C $\beta S$ activity contributes to promote efficient RM processes and maintenance of Met homeostasis but entails as side-effects upstream sequestration of Hcy molecules in biological fluids while decreasing the bioavailability of Cys and GSH working as limiting factors for $\mathrm{H}_{2} \mathrm{~S}$ production. These last adverse effects thus constitute the Achilles heel of a remarkable adaptive machinery.

\section{ROLES PLAYED BY HYDROGEN SULFIDE}

The first demonstration that human tissues may reduce $\mathrm{S}$ to $\mathrm{H}_{2} \mathrm{~S}$ was incidentally provided in 1924 when a man given colloid sulfur for the treatment of polyarthritis did rapidly exhale the typical rotten egg malodor [78] $\mathrm{H}_{2} \mathrm{~S}$ may be produced by the intestinal flora [79] and serves as a metabolic fuel for colonocytes [80]. Prevention of endogenous poisoning by excessive enteral production is insured by the detoxifying activities of mucosal cells [81], hindering any systemic effect of the gaseous substrate. In tissue culture media, the concentrations of sulfane-sulfur is situated at any time below the nanomolar range [71]. The normal $\mathrm{H}_{2} \mathrm{~S}$ concentration measured in mammalian plasmas usually ranges from 10 to $100 \mu \mathrm{M}$ with a mean average turning around $40-50 \mu \mathrm{M}$ $[19,21,82,83]$. This $\mathrm{H}_{2} \mathrm{~S}$ plasma level, appearing as the net product of organs possessing $\mathrm{C} \beta \mathrm{S}$ and $\mathrm{C} \gamma \mathrm{L}$ enzymes and supplemented by the non-enzymatic conversion of $\mathrm{S}$, flows transiently into the vasculature and freely penetrates into all body cells. Supposing that the gaseous reductant is evenly distributed in total body water $(45 \mathrm{~L}$ in a $70 \mathrm{~kg}$ reference man) allows an estimate of bioavailable $\mathrm{H}_{2} \mathrm{~S}$ pool turning around $2 \mathrm{mM}$ which represents, in terms of $\mathrm{S}$ participation, largely less than $1 / 1,000$ of TBS. The peculiar adaptive physiology of vegetarian subjects renders very unlikely that their TBS pool might be solicited to release S-substrates prone to undergo conversion to nascent $\mathrm{H}_{2} \mathrm{~S}$ molecules since they adapt to declining energy and nutrient intakes by switching overall body economy toward downregulated steady state activities. The release from TBS of substantial amounts of S-compounds occurs only during the onset of hypercatabolic states as documented in trauma patients [31] and in infectious diseases [84], exacting as preliminary step cytokine-induced breakdown of tissue proteins, a selective hallmark of stressful disorders [85]. As a result, the limited disposal of $\mathrm{H}_{2} \mathrm{~S}$ endogenously produced might be readily exhausted in fulfilling ROS scavenging tasks at the site of oxidative lesions. All body organs generating $\mathrm{H}_{2} \mathrm{~S}$ from TS enzymes are indeed simultaneously producers and consumers of the gaseous substrate whose actual concentration reflects the balance between synthetic and catabolic rates owing to an estimated biological half-life of less than $30 \mathrm{~min}-$ utes in mammalian plasma [86]. The data are consistent with clinical investigations showing that $\mathrm{H}_{2} \mathrm{~S}$ concentrations found in cerebral homogenates from Alzheimer's disease (AD) patients are very much lower than expected from values measured in healthy brains [87], suggesting that the gaseous messenger is locally submitted to enhanced consumption rates reflecting disease severity. The concept is strongly supported by studies pointing to the negative correlation linking the severity of $\mathrm{AD}$ to $\mathrm{H}_{2} \mathrm{~S}$ plasma values [88].
Similar findings are described in pediatric [89] and elderly [90] hypertensive patients indicating, here gain, that more severe HHcy-dependent oxidative burden is associated with more intense $\mathrm{H}_{2} \mathrm{~S}$ uptake rates. These $\mathrm{H}_{2} \mathrm{~S}$ cleansing properties are mainly exerted by mitochondrial organelles known to be centrally involved in oxidative disorders [20,91]. Malnourished subjects deprived of Cys and GSH disposal thus incur the risk of $\mathrm{H}_{2} \mathrm{~S}$-deficiency rendering them unable to properly overcome HHcy-imposed oxidative lesions. The rapid exhaustion of $\mathrm{H}_{2} \mathrm{~S}$ stores have detrimental consequences as shown a contrario by converging animal experiments and tissue cultures disclosing the beneficial effects of exogenous administration of commonly used sulfide salt donors $\left(\mathrm{Na}_{2} \mathrm{~S}\right.$ and NaHS) generating $\mathrm{H}_{2} \mathrm{~S}$ gas once in solution. Such supply significantly augments $\mathrm{H}_{2} \mathrm{~S}$ plasma concentrations allowing to counteract ROS damages.

$\mathrm{H}_{2} \mathrm{~S}$ was primarily recognized as a physiological substrate working as neuromodulator [92] and soon later as vasorelaxant factor [65]. $\mathrm{H}_{2} \mathrm{~S}$ is now regarded as endowed with a broader spectrum of biological properties [18], operating as a general protective mediator striving against most degenerative organ injuries, being capable of neutralizing or abolishing most ROS harmful effects. Table 1 collects findings displaying that $\mathrm{H}_{2} \mathrm{~S}$ may promote the synthesis and activity of several anti-oxidative enzymes (catalases, $\mathrm{Cu}$ - and Mn-superoxide dismutases, GSH-peroxidases) and stimulate the production of anti-inflammatory reactants (interleukin10) or conversely downregulate pro-oxidative enzymes (collagenases, elastases), pro-inflammatory cytokines (interleukine- $1 \beta$, tumor-necrosis factor $\alpha$ ) and immune reactions (hyperleukocytosis, diapedesis, phagocytosis). It has been calculated that, at physiological $\mathrm{pH}$ (7.4) and body temperature $\left(37^{\circ} \mathrm{C}\right)$, about $18.5 \%$ of $\mathrm{H}_{2} \mathrm{~S}$ remains undissociated whereas $81.5 \%$ undergoes catabolic disintegration in the form of hydrosulfide anion $\left(\mathrm{HS}^{-}\right)$or sulfide anion $\left(\mathrm{S}^{2-}\right)$ [117]. Since $\mathrm{S}$ is the main element comprised in the diprotonated $\mathrm{H}_{2} \mathrm{~S}$ molecule (34.08 as molecular mass), we postulate that partial or complete repair of HHcy-induced lesions constitutes the therapeutic proof that S-deficiency is causally involved in the development of ROS damages. The concept is sustained by the observation that all synthetic drugs (diclofenac, indomethacine, sildenafil) utilized as surrogate providers of $\mathrm{H}_{2} \mathrm{~S}$ $[64,118]$ are characterized by a large diversity of molecular conformations but share in common the presence of Satom(s) mimicking, once released, $\mathrm{H}_{2} \mathrm{~S}$-like pharmacological properties. It remains to be clarified whether the beneficial effects of S-fortification to S-deficient subjects are mediated, among other possible mechanisms, via stimulation $[73,74]$ of anti-oxidative enzymes or inhibition $[75,76]$ of pro-oxidative enzymes. The true RDA requirements for elemental $\mathrm{S}_{8}$ are presently unknown in human nutrition and it is only very recently that the essentiality of $\mathrm{S}$ has been recognized, causing Hcy elevation in deficient individuals [119]. It is worth reminding that the gaseous NO substrate may work in concert or antagonistically $[66,83]$ to fine-tuning the helpful properties exerted by $\mathrm{H}_{2} \mathrm{~S}$ on body tissues. Preliminary studies suggest for instance that NO operates, in combination with $\mathrm{H}_{2} \mathrm{~S}$, as a potential modulator of endothelial remodeling since NO-synthase isoforms contribute to the activation of metalloproteinases involved in the regulation of the collagen/elastin balance defining vascular elastance $[83,120]$. 
Table 1. Reversal of HHcy-Induced Oxidative Damages by Administration of Exogenous $\mathrm{H}_{2} \mathrm{~S}$

\begin{abstract}
BRAIN EFFECTS
$\mathrm{H}_{2} \mathrm{~S}$ is overproduced in response to neuronal excitation [93]. Increases the sensitivity of N-methyl-D-aspartate (NMDA) reactions to glutamate in hippocampal neurons allowing to enhance synaptic transmission [23,94]. Improves long-term potentiation, a synaptic model of memory [92,93]. Stimulates the inhibitory effects of catalase and superoxide dismutase (SOD) in oxidative stress of mouse brain endothelial cells [95]. Regulates Ca ${ }^{2+}$ homeostasis in microglial cells [96]. Inhibits $\mathrm{TNF}_{\alpha}$ expression in microglial cultures [97]. Protects brain cells from neurotoxicity by preventing the rise of ROS in mitochondria [98].
\end{abstract}

\title{
CARDIOVASCULAR EFFECTS
}

$\mathrm{H}_{2} \mathrm{~S}$ releases vascular smooth muscle, inhibits platelet aggregation and reduces the force output of the left ventricule of the heart [18]. Maintains vascular smooth muscle tone [66] and insures protection against arterial hypertension [99]. Modifies leucocyte-vascular epithelium interactions in vivo by modulating leucocyte adhesion and diapedesis at the site of inflammation [100]. Attenuates myocardial ischemia-reperfusion injury by depressing IL-1 $\beta$ and mitochondrial function [20]. Upregulates the expression of depressed anti-oxidative enzymes in heart infarction and inhibits myocardial injury [21]. Alleviates smooth muscle pain by stimulating $\mathrm{K}^{+}$ATP channels [101]. Prevents apoptosis of human neutrophil cells by inhibiting p38 MAP kinase and caspase 3 [102]. Potentiates angiogenesis and wound healing [103].

\section{RENAL EFFECTS}

$\mathrm{H}_{2} \mathrm{~S}$ downregulates the increased activity of metalloproteinases 2 and 9 involved in extracellular matrix degradation (elastases, collagenases) [19]. Prevents apoptotic cell death in renal cortical tissues [19]. Improves the expression of desmin (marker of podocyte injury) and restores the drop of nephrin (component of normal slit diaphragm) in the cortical tissues resulting in reduced proteinuria [19]. Induces hypometabolism revealing protective effects on renal function and survival [104]. Normalizes GSH status and production of ROS in renal diseases [19]. Controls renal ischemia-reperfusion injury and dysfunction [105]. Depresses the expression of inflammatory molecules involved in glomerulosclerosis [106]. Increases renal blood flow, glomerular filtration and urinary $\mathrm{Na}^{+}$excretion [77].

\section{OTHER ORGAN EFFECTS}

$\mathrm{H}_{2} \mathrm{~S}$ insures protection against ROS stress in gastric mucosal epithelia [22]. Accelerates gastric ulcer healing [107]. Reduces gastric injury caused by nonsteroidal anti-inflammatory drugs [108]. Relaxes ileal smooth muscle tone and increases colonic secretions [79]. Attenuates intestinal ischemia-reperfusion injury by increasing SOD and GSH peroxidase status [109]. Stimulates insulin secretion [110] and controls inflammatory events associated with acute pancreatitis [111]. Alleviates hepatic ischemia-reperfusion injury [112]. Prevents lung oxidative stress in hypoxic pulmonary hypertension caused by low GSH content [113]. Promotes SOD and catalase activities and reduces the production of malondialdehyde in oxidative lung injury [114]. Reduces lung inflammation and remodeling in asthmatic animals [115] and in pulmonary hypertension [116].

\section{SUBCLINICAL MALNUTRITION AS WORLDWIDE SCOURGE}

A growing body of data collected along the last decades indicates that large proportions of mankind still suffer varying degrees of protein and energy deficiency that is associated with increased morbidity and mortality rates. The determinants of malnutrition are complex and interrelated, comprising socio-economic and political conditions, insufficient dietary intakes, inadequate caring practices and superimposed inflammatory burden. Children living in developing countries are paying a heavy toll to chronic malnutrition $[121,122]$ whereas adult populations are handicapped by feeble physical and working capacities, increased vulnerability to infectious complications and reduced life expectancy $[123,124]$. Cross-sectional studies collected in the eighties indicate that chronic malnutrition remains a worldwide scourge with top prevalence recorded in Asia, whereas subSaharan Africa endures medium nutritional distress and Latin America appears as the least affected [125,126]. Along the last decades, significant progresses have been achieved in some countries such as Vietnam [127] and Bangladesh [128] owing to appropriate education programs and improved economic development. Inequalities however persist between middle class population groups mainly located in affluent urban areas and underprivileged rural communities remaining stagnant on the sidelines of household income growth. Representative models of these socio-economic disparities in global nutrition and health are illustrated in the two most populated countries in the world, China and India. Large surveys undertaken in 105 counties of China and recently published have concluded that the rural communities haven't yet reach the stage of overall welfare [129]. In India, similar investigations have documented that extreme poverty still prevails in the northern mountainous states of the subcontinent [130]. Taken together, southern Asian countries fail to overcome malnutrition burden [131]. In some African countries, there exists even upward trends suggesting nutritional deterioration over the years [132] still aggravated by a severe drought.

The assessment of malnutrition in children usually rely on anthropometric criteria such as height-for-age, weightfor-height, mid upper arm circumference and skinfold thickness allowing to draw the degree of stunting and wasting from these estimates. In adult subjects, BW and BMI are currently selected parameters to which some biochemical measurements are frequently added, notably SA, classical marker of protein nutritional status, and creatininuria ( $\mathrm{u}-\mathrm{Cr}$ ), held as indicator of sarcopenia. The former biometric approaches are very useful in that they correctly provide a static picture of the declared stages of malnutrition but fail to recognize the dynamic mechanisms occurring during the preceding months and the adaptive alterations running behind. The National Center for Health Statistics / WHO reference Tables must therefore be regarded as theoretical guide- 
lines defining minimum risk distribution of underweight [133]. The validity of the latter biological analytes may similarly be questioned since it is known for a while that SA is an insensitive marker of protein-depleted states compared to TTR [134] and a better indicator of population than of individual protein status. $\mathrm{u}-\mathrm{Cr}$ is likewise a meagerly informative tool as $10 \%$ loss of muscle mass is required before it reaches significantly decreased urinary concentrations [135]. The data imply that the magnitude of subclinical malnutrition is largely underscored when classical biometric and laboratory investigations are performed. Moreover, ruling out the protein component involved in HHcy epidemiology and confining solely attention to the B-vitamin triad led to unachieved conclusions. For instance, surveys undertaken in Taiwan [136] and in India [137] did establish HHcy variance turning around $30 \%$, indicating that a sizeable percentage of subjects do not come within the vitamin shortage concept. To our knowledge, there exists only one recent review recommending the use of TTR in vegetarian subjects [138]. The main reason for making the choice of TTR is grounded on the striking similar plasma profile disclosed by this marker with both LBM and Hcy [29]. Under healthy conditions, the 3 parameters indeed show low concentrations at birth, linear increase without sexual difference in preadolescent children, gender dimorphism in teenagers with higher values recorded in adolescent male subjects and thereafter maintenance of distinct plateau levels during adulthood [29,139,140]. Under morbid circumstances, the plasma concentrations of Hcy manifest gradual elevation negatively correlated with LBM downsizing and TTR decline. In vegetarian subjects and subclinically malnourished patients, rising Hcy and diminished TTR plasma concentrations look as mirror image of each other, revealing divergent distortion from normal and allowing early detection of preclinical steps at the very same time both $\mathrm{SA}$ and $\mathrm{u}-\mathrm{Cr}$ markers still remain silent.

Any disease process characterized by quantitative or qualitative dietary protein restriction or intestinal malabsorption may cause LBM shrinking, downregulation of TTR concentrations and subsequent HHcy upsurge. These conditions are documented in frank kwashiorkor [141], subclinical protein restriction [27,43] and anorexia nervosa [142]. In patients submitted to weight-reducing programs, LBM was found the sole independent variable negatively correlated with rising Hcy values [143]. Morbid obesity may be alleviated by medical treatment [143] or surgical gastroplasty $[144,145]$, conditions frequently associated with secondary malabsorptive syndromes and malnutrition [146], rendering an account of acquired HHcy. In westernized countries, subclinical protein-depleted states are illustrated in immigrants originating from developing regions but keeping alive their traditional feeding practices [147] or by communities having adopted, for socio-cultural reasons, strict vegan dietary lifestyles [148].

\section{THE ADDITIONAL BURDEN OF S-DEFICIENCY}

After $\mathrm{N}, \mathrm{K}$ and $\mathrm{P}$, elemental $\mathrm{S}$ is recognized as the fourth most important macronutrient required for plant development. The essentiality of $S$ in the vegetable kingdom arose from observations made many decades ago by pedologists and agronomists $[149,150]$ revealing that the withdrawal of sulfate salts from nutrient sources produces rapid growth retardation, depressed chlorophyllous synthesis, yellowing of leaves and reduction in fertility and crop yields. A large number of field studies, mainly initiated for economical reasons, has provided continuing gain in fundamental and applied knowledge and led to the overall consensus that $\mathrm{SO}_{4}{ }^{2-}$ deficiency is a major wordwide problem [151,152]. Field investigations have shown that the concentration of $\mathrm{SO}_{4}{ }^{2-}$ oxyanions in soils and drinking waters may reveal considerable variations ranging from less than $2 \mathrm{mg} / \mathrm{L}$ to more than 1 $\mathrm{g} / \mathrm{L}$, meaning a ratio exceeding $1 / 500$ under extreme circumstances [30]. The main causal factors responsible for unequal distribution of $\mathrm{SO}_{4}{ }^{2-}$ oxyanions are geographical distance from eruptive sites and intensity of soil weathering in rainy countries. $\mathrm{SO}_{4}{ }^{2-}$-dependent nutritional deficiencies entail detrimental effects to most African and Latin American crops [151] reaching nevertheless top incidence in southeastern Asia [151,153]. One of the most depleted area is the Indo-Gangetic plain extending from Pakistan to Bangladesh and covering the North of India and Nepal [154]. Intensive agricultural production, lack of animal manure and use of fertilizers providing $\mathrm{N}, \mathrm{K}$ and $\mathrm{P}$ substrates but devoid of sulfate salts may further aggravate that imbalanced situation. As global population increases steadily and the production of staple plants predicted to escalate considerably, $\mathrm{SO}_{4}{ }^{2-}$ deficient disorders are expected to become more pregnant along the coming years [155] with significant harmful impact for mankind. Nevertheless, effective preventive efforts are developed in some countries aiming at fortification of soils mainly by ammonium sulfate or calcium sulfate (gypsum) salts, resulting in meaningful improvements in crop yield, SAAs content and biological value and opening more optimistic perspectives for livestock and human consumption [152,155-158].

Contrasting with the tremendously high amounts of data accumulated over decades by pedologists and agronomists on sulfate requirements and metabolism, the available knowledge on elemental sulfur in human nutrition looks like a black hole. Despite the fact that $\mathrm{S}_{8}$ follows $\mathrm{H}, \mathrm{C}, \mathrm{O}, \mathrm{N}, \mathrm{Ca}$ and $\mathrm{P}$ as the sevenmost abundant element in mammalian tissues, it appears as a forgotten item. Not the slightest attention is dedicated to $\mathrm{S}_{8}$ in the authoritative "Present Knowledge in Nutrition" series of monographs even though they go over most oligo- and trace-elements in minute detail. The geographical distribution of $\mathrm{S}_{8}$ throughout earth's crust is not well-known as extreme paucity of measurements in soils and tap waters prevents from reaching a comprehensive overview. Nevertheless, and because $S_{8}$ is the obligatory precursor substrate for the oxidative production of sulfate salts, a decremental dispersion pattern paralleling those of $\mathrm{SO}_{4}{ }^{2-}$ oxyanions is likely to occur with highest values recorded in the vicinity of volcano sources and lowest values found in remote and washed-out areas. Obviously, a great deal of research on elemental $\mathrm{S}$ remains to be completed by clinical biochemists before rejoining the status of plant agronomy.

Taken together, these data imply that subclinically malnourished subjects living in areas recognized as $\mathrm{SO}_{4}{ }^{2-}$ deficient for the vegetable kingdom also incur increased risks to become $S_{8}$-depleted. This clinical entity most probably prevails in all regions, notably Northern India, where protein malnutrition [130] and sulfur-deficiency [154] coexist. Combination of both nutritional deprivations explains why the bulk of local dwellers, including young subjects $[159,160]$, may develop HHcy states and CVD disorders 
characterized by strong refractoriness to vitamin-B supplementation [160] or high incidence of stroke [161] unrelated to the classical Framingham criteria. The current consensus is that "the problem of CVD in South Asia is different in etiology and magnitude from other parts of the world" [162]. These disquieting findings are confirmed in several Asian countries [163] and have prompted local cardiologists to exhort their governments to focus more attention on CVD epidemiology [164].

\section{CONCLUDING REMARKS}

The main lesson to learn from the present review is that vegetarian subjects are not protected against the risk of CVD and stroke which should no longer be regarded as solely affecting populations living in westernized societies and whose morbidity and mortality risks are stratified by classical Framingham criteria. Likewise hypercholesterolemia, hyperhomocysteinemia should be incriminated as emblematic risk factor for a panoply of CVD and related disorders. Whereas the causality of cholesterol and lipid fractions largely prevails in affluent societies consuming high amounts of animal-based items, that of homocysteine predominates in population groups whose dietary lifestyle gives more importance to plant products.

\section{ACKNOWLEDGEMENT}

None Declared.

\section{CONFLICT OF INTEREST}

None Declared.

\section{REFERENCES}

[1] McCully, K.S. Vascular pathology of homocysteinemia: implications for the pathogenesis of arteriosclerosis. Am. J. Pathol., 1969, $56,111-128$.

[2] Ubbink, J.B.; van der Merwe, A.; Delport, R.; Allen, R.H.; Stabler, S.P.; Riezler, R.; Vermaak, W.J. The effect of subnormal vitamin B-6 status on homocysteine metabolism. J. Clin. Invest., 1996, 98, 177-184

[3] Kang, S.S.; Wong, P.W.; Norusis, M. Homocysteinemia due to folate deficiency. Metabolism, 1987, 36, 458-462.

[4] Stabler, S.P.; Allen, R.H.; Savage, D.G.; Lindenbaum, J. Clinical spectrum and diagnosis of cobalamin deficiency. Blood, 1990, 76, $871-881$.

[5] Yan, S.K.; Chang, T.; Wang, H.; Wu, L.; Wang, R.; Meng, Q.H. Effects of hydrogen sulfide on homocysteine-induced oxidative stress in vascular smooth muscle cells. Biochem. Biophys. Res. Commun., 2006, 351, 485-491.

[6] Cheng, Z.; Yang, X.; Wang, H. Hyperhomocysteinemia and endothelial dysfunction. Curr. Hypertens. Rev., 2009, 5,158-165.

[7] Loscalzo, J. The oxidant stress of hyperhomocyst(e)inemia. J. Clin. Invest., 1996, 98, 5-7.

[8] Jacobsen, D.W. Hyperhomocysteinemia and oxidative stress: Time for a reality check ? Arterioscler. Thromb. Vasc. Biol., 2000, 20, 1182-1184.

[9] Packer, L.; Cadenas, E. Oxidants and antioxidants revisited. New concepts of oxidative stress. Free Rad. Res., 2007, 41, 951-952.

[10] McCully, K.S. Chemical pathology of homocysteine: IV. Excitotoxicity, oxidative stress, endothelial dysfunction, and inflammation. Annals Clin. Lab. Sci., 2009, 39, 219-232.

[11] Bautista, L.E.; Arenas, I.A.; Penuela, A.; Martinez, I.X. Total plasma homocysteine level and risk of cardiovascular disease: a meta-analysis of prospective cohort studies. J. Clin. Epidemiol., 2002, 55, 882-887.

[12] Furie, K.L.; Kelly, P. J. Homocyst(e)ine and stroke. Semin. Neurol., 2006, 26, 24-32.
[13] Van Guldener, C. Homocysteine and the kidney. Curr. Drug Metab., 2005, 6, 23-26.

[14] McCaddon, A.; Davies, G.; Hudson, P.; Tandy, S.; Cattell, H. Total serum homocysteine in senile dementia of Alzheimer type. Int. J. Geriatr. Psychiatry 1998, 13, 235-239.

[15] Troen, A.M.; Rosenberg, I.H. Homocysteine and cognitive function. Semin. Vasc. Med., 2005, 5, 209-214.

[16] Danese, S.; Sgambato, A.; Papa, A.; Scaldaferri, F.; Pola, R.; Sans, M.; Lovecchio M. Homocysteine triggers mucosal microvascular activation in inflammatory bowel disease. Am. J. Gastroenterol., 2005, 100, 886-895.

[17] van Meurs, J.B.; Dhonukshe-Rutten, R.A.; Pluijm, S.M.; van der Klift, M.; de Jonge, R.; Lindemans, J.; de Groot, L.; Hofman, A.; Witteman, J.; van Leeuwen, J.; Breteler, M.; Lips, P.K; Pols, H.; Uitterlinden, A.G. Homocysteine levels and the risk of osteoporotic fracture. N. Engl. J. Med., 2004, 350, 2033-2041.

[18] Wang, R. Two's company, three's a crowd: can $\mathrm{H}_{2} \mathrm{~S}$ be the third endogenous gaseous transmitter ? FASEB J., 2002, 16, 1792-1798.

[19] Sen, U.; Basu, P.; Abe, O.A.; Givvimani, S.; Tyagi, N.; Metreveli, N.; Shah, K.S.; Passmore, J.C.; Tyagi S.C. Hydrogen sulfide ameliorates hyperhomocysteinemia-associated chronic renal failure. Am. J. Physiol. Renal Physiol., 2009, 297, F 410-419.

[20] Elrod, J.W.; Calvert, J.W.; Morrison, J.; Doeller, J.E.; Kraus, D.W.; Tao, L.; Jiao, X.; Scalia, R.; Kiss, L.; Szabó, C.; Kimura, H.; Chow, C.W.; Lefer, D.J. Hydrogen sulfide attenuates myocardial ischemia-reperfusion injury by preservation of mitochondrial function. Proc. Natl. Acad. Sci. USA, 2007, 104, 15560-15565.

[21] Chang, L.; Geng, B.; Yu, F.; Zhao, J .; Jiang, H.; Du, J.; Tang C. Hydrogen sulfide inhibits myocardial injury induced by homocysteine in rats. Amino Acids, 2008, 34, 573-585.

[22] Yonezawa, D.; Sekiguchi, F.; Miyamoto, M.; Taniguchi, E.; Honjo, M.; Masuko, T.; Nishikawa, H.; Kawabata, A. A protective role of hydrogen sulfide against oxidative stress in rat gastric mucosal epithelium. Toxicology, 2007, 241, 11-18.

[23] Dominy, J.E.; Stipanuk, M.H. New roles for cysteine and transulfuration enzymes: production of $\mathrm{H}_{2} \mathrm{~S}$, a neuromodulator and smooth muscle relaxant. Nutr. Rev. 2004, 62, 348-353.

[24] Singh, S.; Padovani, D.; Leslie, R.A.; Chiku, T.; Banerjee, R. Relative contributions of cystathionine $\beta$-synthase and $\gamma$-cystathionase to $\mathrm{H}_{2} \mathrm{~S}$ biogenesis via alternative trans-sulfuration reactions. J. Biol. Chem., 2009, 284, 22457-22466.

[25] Searcy, D.G.; Lee, S.H. Sulfur reduction by human erythrocytes. $J$. Exp. Zool. 1998, 282, 310-322.

[26] Benavides, G.A.; Squadrito, G.L.; Mills, R.W.; Patel, H.D.; Isbell, T.S.; Patel, R.P.; Darley-Usmar, V.M.; Doeller, J.E.; Kraus, D.W Hydrogen sulfide mediates the vasoactivity of garlic. Proc. Natl. Acad. Sci. USA, 2007, 104, 17977-19982.

[27] Ingenbleek, Y.; McCully, K. Vegetarianism produces subclinical malnutrition, hyperhomocysteinemia and atherogenesis. Nutrition. Doi:10.1016/j.nut.2011.04.009: on line 27 ${ }^{\text {th }}$ August 2011.

[28] Battezzatti, A.; Bertoli, S.; San Romerio, A.; Testolin, G. Body composition: an important determinant of homocysteine and methionine concentrations in healthy individuals. Nutr. Metab. Cardiovasc. Dis., 2007, 17, 525-534.

[29] Ingenbleek, Y. Plasma Transthyretin Reflects the Fluctuations of Lean Body Mass in Health and Disease. In: Recent Advances in Transthyretin Evolution, Structure and Biological Functions, Richardson, S.J. and Cody, V., Eds.; Springer Verlag : Berlin, 2009, pp. 329-357.

[30] Ingenbleek, Y. The nutritional relationship linking sulfur to nitrogen in living organisms. J. Nutr., 2006, 136, S1641-S1651.

[31] Cuthbertson, D.P. The distribution of nitrogen and sulphur in the urine during conditions of increased catabolism. Biochem. J., 1931, 25, 236-244.

[32] McCance, R.A.; Widdowson, E.M. The Composition of Food. $5^{\text {th }}$ ed., Royal Society of Chemistry: Cambridge, 1991.

[33] Food and Agriculture Organization. Amino-acid Content of Foods and Biological Data on Proteins, FAO: Rome, 1970.

[34] Souci, S.W.; Fachman, W.; Kraut, H. Food Composition and Nutrition Tables. $5^{\text {th }}$ ed., CRC Press: Boca Raton, 1994.

[35] Ingenbleek, Y.; Young, V.R. Significance of transthyretin in protein metabolism. Clin. Chem. Lab. Med., 2002, 40, 1281-1291.

[36] Forbes, G.B. Body Composition. In: Present Knowledge in Nutrition; $7^{\text {th }}$ ed.; Ziegler, E.E. and Filer L.J, Eds.; ILSI Press: Washington D.C. 1996; pp. 7-12. 
[37] Walter, P. Effects of the vegetarian diets on aging and longevity. Nutr. Rev., 1997, 55, S61-S65.

[38] Key, T.J.; Appleby, P.N.; Rosell, M.S. Health effects of vegetarian and vegan diets. Proc. Nutr. Soc., 2006, 65, 35-41.

[39] Young, V.R.; Pellet, P.L. Plant proteins in relation to human protein and amino acid nutrition. Am. J. Clin. Nutr., 1994, 59, S1203S1212.

[40] Friedman, M. Dietary impact of food processing. Annu. Rev. Nutr., 1992, 12, 119-137.

[41] Gilani, G.S.; Cockell, K.A.; Sepehr, E. Effects of antinutritional factors on protein digestibility and amino acid availability in foods. J. AOAC Int., 2005, 88, 967-987.

[42] Ingenbleek, Y.; Barclay, D.; Dirren, H. Nutritional significance of alterations in serum amino acid patterns in goitrous patients. Am. $J$. Clin. Nutr., 1986, 43, 310-319.

[43] Ingenbleek, Y.; Hardillier, E.; Jung, L. Subclinical protein malnutrition is a determinant of hyperhomocysteinemia. Nutrition, 2002, $18,40-46$

[44] Ingenbleek, Y.; Young, V.R. The essentiality of sulfur is closely related to nitrogen metabolism: a clue to hyperhomocysteinemia. Nutr. Res. Rev., 2004, 17, 135-153.

[45] Tang, B.; Mustafa, A.; Gupta, S.; Melnyk, S.; James S.J.; Kruger, W.D. Methionine-deficient diet induces post-transcriptional downregulation of cystathionine- $\beta$-synthase. Nutrition, 2010, 26, 11701175 .

[46] Elshorbagy, A.K.; Valdivia-Garcia, M.; Refsum, H.; Smith, A.D.; Mattocks, D.A.; Perrone, C.E. Sulfur amino acids in methioninerestricted rats: Hyperhomocysteinemia. Nutrition, 2010, 26, 12011204.

[47] Owens, F.N.; Bergen, W.G. Nitrogen metabolism in ruminant animals: historical perspective, current understanding and future implications. J. Anim. Sci., 1983, 57 (Suppl. 2), 498-518.

[48] Fuller, M.F.; McWilliam, R.; Wang, T.C.; Giles, L.R. The optimum dietary amino acid pattern for growing pigs. 2. Requirements for maintenance and for tissue protein accretion. Br. J. Nutr., 1989, 62, 255-267.

[49] Finkelstein, J.D.; Kyle, W.E.; Martin, J.J.; Pick, A.M. Activation of cystathionine synthase by adenosylmethionine and adenosylethionine. Biochem. Biophys. Res. Commun., 1975, 66, 81-87.

[50] Janosik, M.; Kery, V.; Gaustadnes, M.; Maclean, K.N.; Kraus, J.P. Regulation of human cystathionine beta-synthase by S-adenosyl-Lmethionine: evidence for two catalytically active conformations involving an autoinhibitory domain in the C-terminal group. Biochemistry (Mosc.), 2001, 40, 10625-10633.

[51] Jahoor, F.; Badaloo, A.; Reid, M.; Forrester, T. Sulfur amino acid metabolism in children with severe childhood undernutrition : cysteine kinetics. Am. J. Clin. Nutr., 2006, 84, 1400-1405.

[52] Jones, D.P.; Coates, R.J.; Flagg, E.W.; Eley, J.W.; Block, G.; Greenberg, R.S.; Gunter, E.W.; Jackson, B. Glutathione in foods listed in the National Cancer Institute's health habits and history food frequency questionnaire. Nutr. Cancer, 1992, 17, 57-75.

[53] Lyons, J.; Rauh-Pfeiffer, A.; Yu, Y.M.; Lu, X.M.; Zurakowski, D.; Tompkins R.G.; Ajami, A.M.; Young, V.R.; Castillo, L. Blood glutathione synthesis rates in healthy adults receiving a sulfur amino acid-free diet. Proc. Natl. Acad. Sci. USA, 2000, 97, 5071-5076.

[54] Chen, X.; Jhee, K.H.; Kruger, W.D. Production of the neuromodulator $\mathrm{H}_{2} \mathrm{~S}$ by cystathionine $\beta$-synthase via the condensation of cysteine and homocysteine. J. Biol. Chem., 2004, 279, 52082-52086.

[55] Stipanuk, M.H. Sulfur amino acid metabolism : pathways for production and removal of homocysteine and cysteine. Annu. Rev. Nutr., 2004, 24, 539-577.

[56] Stipanuk, M.H.; Ueki, I. Dealing with methionine/homocysteine sulfur : cysteine metabolism to taurine and inorganic sulfur. J. Inherit. Metab. Dis., 2011, 34, 17-32.

[57] Kamoun, P. Endogenous production of hydrogen sulfide in mammals. Amino Acids, 2004, 26, 243-254.

[58] Kimura, H. Hydrogen sulfide : its production, release and functions. Amino Acids, 2011, 41, 113-121.

[59] Enokido, Y.; Suzuki, E.; Iwasawa, K.; Namekata, K.; Okazawa, H.; Kimura, H. Cystathionine $\beta$-synthase, a key enzyme for homocysteine metabolism, is preferentially expressed in the radial glia/astrocyte lineage of developing mouse CNS. FASEB J., 2005, $19,1854-1856$.

[60] Zhao, W.; Ndisang, J.F.; Wang, R. Modulation of endogenous production of $\mathrm{H}_{2} \mathrm{~S}$ in rat tissues. Can. J. Physiol. Pharmacol., 2003, $81,848-853$.
[61] House, J.D.; Brosnan, M.E.; Brosnan, J.T. Characterization of homocysteine metabolism in the rat kidney. Biochem. J., 1997, 328, 287-292.

[62] Dorman, D.C.; Moulin, F.J.; McManus, B.E.; Mahle, K.C.; James, R.A.; Struve, M.F. Cytochrome oxidase inhibition induced by acute hydrogen sulfide inhalation : correlation with tissue sulfide concentrations in the rat brain, liver, lung, and nasal epithelium. Toxicol. Sci., 2002, 65, 18-25.

[63] Barañano, D.E.; Ferris, C.D.; Snyder, S.H. Atypical neural messengers. Trends Neurosci., 2001, 24, 99-106.

[64] Mancardi, D.; Penna, C.; Merlino, A.; Del Soldato, P.; Wink, D.A.; Pagliaro, P. Physiological and pharmacological features of the novel gasotransmitter : Hydrogen sulfide. Biochim. Biophys. Acta, 2009, 1787, 864-872.

[65] Zhao, W.; Zhang, J.; Lu, Y.; Wang, R. The vasorelaxant effect of $\mathrm{H}(2) \mathrm{S}$ as a novel endogenous gaseous K(ATP) channel opener. EMBO J., 2001, 20, 6008-6016.

[66] Hosoki, R.; Matsuki, N.; Kimura, H. The possible role of hydrogen sulfide as an endogenous smooth muscle relaxant in synergy with nitric oxide. Biochem. Biophys. Res. Commun., 1997, 237, 527531.

[67] Geng, B.; Yang, J.; Qi, Y.; Zhao, J.; Pang, Y.; Du, J.; Tang C. $\mathrm{H}_{2} \mathrm{~S}$ generated by heart in rat and its effects on cardiac function. Biochem. Biophys. Res. Commun., 2004, 313, 362-368.

[68] Klimmek, O. The biological cycle of sulfur. Met. Ions Biol. Syst., 2005, 105-130.

[69] Vennesland, B.V.; Castric, P.A.; Conn, E.E.; Solomonson, L.P.; Volini, M.; Westley, J. Cyanide metabolism. Fed. Proc. Fed. Am. Soc. Exp. Biol., 1982, 41, 2639-2648.

[70] Wood, J.L. Sulfane sulfur. Methods Enzymol., 1987, 143, 25-29.

[71] Toohey, J.I. Sulphane sulphur in biological systems: a possible regulatory role. Biochem. J., 1989, 264, 625-632.

[72] Ogasawara, Y.; Isoda, S.; Tanabe, S. Tissue and subcellular distribution of bound and acid-labile sulfur, and the enzymic capacity for sulfide production in the rat. Biol. Pharm. Bull., 1994, 17, 15351542 .

[73] Bonomi, F.; Pagani, S.; Cerletti, P.; Cannella, C. Rhodanesemediated sulfur transfer to succinate dehydrogenase. Eur. J. Biochem., 1977, 72, 17-24.

[74] Pagani, S.; Galante, Y.M. Interaction of rhodanese with mitochondrial NADH dehydrogenase. Biochim. Biophys. Acta, 1983, 742, 278-284.

[75] Russell, P.J.; Conner, J.; Sisson, S. Sulfur specifically inhibits adenylate kinase in assays for creatine kinase. Clin. Chem., 1984, 30, 1555-1557.

[76] Hargrove, J.L.; Wichman, R.D. A cystine-dependent inactivator of tyrosine aminotransferase co-purifies with $\gamma$-cystathionase (cysteine desulfurase). J. Biol. Chem., 1987, 262, 7351-7357.

[77] Xia, M.; Chen, L.; Muh, R.W.; Li, P.L.; Li, N. Production and actions of hydrogen sulfide, a novel gaseous bioactive substance, in the kidneys. J. Pharmacol. Exp. Ther., 2009, 329, 1056-1062.

[78] Monaghan, W.J.; Garai, F. Treatment of acute and chronic polyarthritis, arthritis deformans, and septicemias, with activated colloid sulphur. Med. J. Record, 1924, 120, 24-26.

[79] Fiorucci, S.; Distrutti, E.; Cirino, G.; Wallace, J.L. The emerging role of hydrogen sulfide in the gastrointestinal tract and liver. Gastroenterology, 2006, 131, 259-271.

[80] Goubern, M.; Andriamihaja, M.; Nubel, T.; Blachier, F.; Bouillaud, F. Sulfide, the first inorganic substrate for human cells. FASEB J., 2007, 21, 1699-1706.

[81] Furne, J.; Springfield, J.; Koenig, T.; DeMaster, E.; Levitt, MD. Oxidation of hydrogen sulfide and methanethiol to thiosulfate by rat tissues: a specialized function of the colonic mucosa. Biochem. Pharmacol., 2001, 62, 255-259.

[82] Chen, YH.; Yao, W.Z.; Geng, B.; Ding, Y.L.; Lu, M.; Zhao, M.W.; Tang, C.S. Endogenous hydrogen sulfide in patients with COPD. Chest, 2005, 128, 3205-3211.

[83] Whiteman, M.; Moore, P.K. Hydrogen sulfide and the vasculature: a novel vasculoprotective entity and regulator of nitric oxide bioavailability? J. Cell. Mol. Med., 2009, 13, 488-507.

[84] Breitkreutz, R.; Holm, S.; Pittack, N.; Beichert, M.; Babylon, A.; Yodoi, J.; Dröge, W. Massive loss of sulfur in HIV infection. AIDS Res. Hum. Retroviruses, 2000, 16, 203-209.

[85] Ingenbleek, Y.; Bernstein, L. The stressful condition as a nutritionally dependent adaptive dichotomy. Nutrition, 1999, 15, 305-320. 
[86] Whitfield, N.L.; Kreimier, E.L.; Verdial, F.C.; Skovgaard, N.; Olson, K.R. A reappraisal of $\mathrm{H}_{2} \mathrm{~S} /$ sulfide concentration in vertebrate blood and its potential significance in ischemic preconditioning and vascular signaling. Am. J. Physiol. Regul. Integr. Comp. Physiol., 2008, 294, R1930-1937.

[87] Eto, K.; Asada, T.; Arima, K.; Makifuchi, T.; Kimura, H. Brain hydrogen sulfide is severely decreased in Alzheimer's disease. Biochem. Biophys. Res. Commun., 2002, 293, 1485-1488.

[88] Liu, X.Q.; Liu, X.Q.; Jiang, P.; Huang, H.; Yan, Y. Plasma levels of endogenous hydrogen sulfide and homocysteine in patients with Alzheimer's disease and vascular dementia and the significance thereof. Zhonghua Yi Xue Za Zhi, 2008, 88, 2246-2249.

[89] Chen, L.; Ingrid, S.; Ding, Y.G.; Liu, Y.; Qi, J.G.; Tang, J.B. Imbalance of endogenous homocysteine and hydrogen sulfide metabolic pathway in essential hypertensive children. Chin. Med. J., 2007, 120, 389-393.

[90] Sun, N.L.; Xi, Y.; Yang, S.N.; Ma, Z.; Tang, C.S. Plasma hydrogen sulfide and homocysteine levels in hypertensive patients with different blood pressure levels and complications. Zonghua Xin Xue Guan Bing Za Zhi, 2007, 35, 1145-1148.

[91] Lin, M.T.; Beal, M.F. Mitochondrial dysfunction and oxidative stress in neurodegenerative diseases. Nature, 2006, 443, 787-795.

[92] Abe, K.; Kimura, H. The possible role of hydrogen sulfide as an endogenous neuromodulator. J. Neurosci., 1996, 16, 1066-1071.

[93] Eto, K.; Ogasawara, M.; Umemara, K.; Nagai, Y.; Kimura, H. Hydrogen sulfide is produced in response to neuronal excitation. $J$. Neurosci., 2002, 22, 3386-3391.

[94] Qu, K.; Lee, S.W.; Bian, J.S.; Low, C.M.; Wong, P.T. Hydrogen sulfide : neurochemistry and neurobiology. Neurochem. Int., 2007, $52,155-165$.

[95] Tyagi, N.; Moshal, K.S.; Sen, U.; Vacek, T.P.; Kumar, M.; Hughes, W.M. Jr.; Kundu, S.; Tyagi, S.C. $\mathrm{H}_{2} \mathrm{~S}$ protects against methionineinduced oxidative stress in brain endothelial cells. Antioxid. Redox. Signal, 2009, 11, 25-33.

[96] Lee, S.W.; Hu, Y.S.; Hu, L.F.; Lu, O.; Dawe, G.S.; Moore, P.K.; Wong, P.T.; Bian, J.S. Hydrogen sulfide regulates calcium homeostasis in microglial cells. Glia, 2006, 54, 116-124.

[97] Hu, L.F.; Wong, P.T.; Moore, P.K.; Bian, J.S. Hydrogen sulfide attenuates lipopolysaccharide-induced inflammation by inhibition of p38 mitogen-activated protein kinase in microglia. $J$. Neurochem., 2007, 100, 1121-1128.

[98] Tang, X.Q.; Shen, X.T.; Huang, Y.E.; Ren, Y.K.; Chen, R.Q.; Hu, B.; He, J.Q.; Yin, W.L.; Xu, J.H.; Jiang, Z.S. Hydrogen sulfide antagonizes homocysteine-induced neurotoxicity in $\mathrm{PC}_{12}$ cells. Neurosci. Res., 2010, 68, 241-249.

[99] Yang, G.; Wu, L.; Jiang, B.; Yang, W.; Qi, J.; Cao, K.; Meng, Q.; Mustafa, A.K.; Mu, W.; Zhang, S. $\mathrm{H}_{2} \mathrm{~S}$ as a physiologic vasorelaxant : hypertension in mice with deletion of cystathionine gammalyase. Science, 2008, 322, 587-590.

[100] Zanardo, R.C.; Brancaleone, V.; Distrutti, E.; Fiorucci, S.; Cirino, G.; Wallace, J.L. Hydrogen sulfide is an endogenous modulator of leukocyte-mediated inflammation. FASEB J., 2006, 20, 2118-2120.

[101] Tang, G.; Wu, L.; Liang, W.; Wang, R. Direct stimulation of K(ATP) channels by exogenous and endogenous hydrogen sulfide in vascular smooth muscle cells. Mol. Pharmacol., 2005, 68, 17571764.

[102] Rinaldi, L.; Gobbi, G.; Pambianco, M.; Micheloni, C.; Mirandola, P.; Vitale, M. Hydrogen sulfide prevents apoptosis of human PMN via inhibition of p38 and caspase 3. Lab. Invest., 2006, 86, 391397.

[103] Papapetropoulos, A.; Pyriochou, A.; Altaany, Z.; Yang, G.; Marazioti, A.; Zhou, Z.; Jeschke, M.G.; Branski, L.K.; Herndon, D.N.; Szabó, C. Hydrogen sulfide is an endogenous stimulator of angiogenesis. Proc. Natl. Acad. Sci. USA, 2009, 106, 21972-21977.

[104] Bos, E.M.; Leuvenink, H.G.; Snijder, P.M.; Kloosterhuis, N.J.; Hillebrands, J.L.; Leemans, J.C.; Florquin, S.; van Goor, H. Hydrogen sulfide-induced hypometabolism prevents ischemia / reperfusion injury. J. Am. Soc. Nephrol., 2009, 20, 1901-1905.

[105] Tripatara, P.; Patel, N.S.; Collino, M.; Gallichio, M.; Kieswich, J.; Castiglia, S.; Benetti, E.; Stewart, K.N.; Brown, P.A.; Yaqoob, M.M.; Fantozzi, R.; Thiemermann, C. Generation of endogenous hydrogen sulfide by cystathionine gamma-lyase limits renal ischemia/reperfusion injury and dysfunction. Lab. Invest., 2008, 88, 1038-1048.
[106] Sen, U.; Munjal, C.; Qipshidze, N.; Abe, O.; Gargoum, R.; Tyagi, S.C. Hydrogen sulfide regulates homocysteine-mediated glomerulosclerosis. Am. J. Nephrol., 2010, 31, 442-455.

[107] Wallace, J.L.; Dicay, M.; McKnight, W.; Martin, G.R. Hydrogen sulfide enhances ulcer healing in rats. FASEB J., 2007, 21, 40704076.

[108] Fiorucci, S.; Antonelli, E.; Distrutti, E.; Rizzo, G.; Mencarelli, A.; Orlandi S.; Zanardo, R.; Renga, B.; Di Sante, M.; Morelli, A.; Cirino, G.; Wallace, J.L. Inhibition of hydrogen sulfide generation contributes to gastric injury caused by anti-inflammatory nonsteroidal drugs. Gastroenterology, 2005, 129, 1210-1224.

[109] Liu, H.; Bai, X.B.; Shi, S.; Cao, Y.X. Hydrogen sulfide protects from intestinal ischaemia-reperfusion injury in rats. J. Pharm. Pharmacol., 2009, 61, 207-212.

[110] Yang, W.; Yang, G.; Jia, X.; Wu, L.; Wang, R. Activation of $\mathrm{K}_{\mathrm{ATP}}$ channels by $\mathrm{H}_{2} \mathrm{~S}$ in rat insulin-secreting cells and the underlying mechanism. J. Physiol., 2005, 569, 519-531.

[111] Tamizhselvi, R.; Moore, P.K.; Bhatia, M. Hydrogen sulfide acts as a mediator of inflammation in acute pancreatitis: in vitro studies using isolated mouse pancreatic acinar cells. J. Cell. Mol. Med., 2007 $11,315-326$

[112] Kang, K.; Zhao, M.; Jiang, H.; Tan, G.; Pan, S.; Sun, X. Role of hydrogen sulfide in hepatic ischemia-reperfusion-induced injury in rats. Liver Transpl., 2009, 15, 1306-1314.

[113] Wei, H.L.; Zhang, C.Y.; Jin, H.F.; Tang, C.S.; Du, J.B. Hydrogen sulfide regulates lung tissue-oxidized glutathione and total antioxidant capacity in hypoxic pulmonary hypertensive rats. Acta Pharmacol. Sin., 2008, 29, 670-679.

[114] Fu, Z.; Liu, X.; Geng, B.; Fang, L.; Tang, C. Hydrogen sulfide protects rat lung from ischemia-reperfusion injury. Life Sci., 2008, 82, 1196-1202.

[115] Chen, Y.H.; Wu, R.; Geng, B.; Qi, Y.F.; Wang, P.P.; Yao, W.Z.; Tang, C.S. Endogenous hydrogen sulfide reduces airway inflammation and remodeling in a rat model of asthma. Cytokine 2009, 45, 117-123.

[116] Li, X.; Jin, H.; Bin, G.; Wang, L.; Tang, C.; Du, J. Endogenous hydrogen sulfide regulates pulmonary artery collagen remodeling in rats with high pulmonary blood flow. Exp. Biol. Med. (Maywood), 2009, 234, 504-512.

[117] Dombkowski, R.A.; Russell, M.J.; Olson, K.R. Hydrogen sulfide as an endogenous regulator of vascular smooth muscle tone in trout. Am. J. Physiol. Regul. Integr. Comp. Physiol., 2004, 286, R678R685.

[118] Wallace, J.L. Hydrogen sulfide-releasing anti-inflammatory drugs. Trends Pharmacol. Sci., 2007, 28, 501-505.

[119] Ingenbleek, Y. Hyperhomocysteinemia is a biomarker of sulfurdeficiency in human morbidities. Open Clin. Chem. J., 2009, 2, 4960 .

[120] Steed, M.M.; Tyagi, S.C. Mechanisms of cardiovascular remodeling in hyperhomocysteinemia. Antioxid. Redox. Signal., 2011, 15, 1927-1943.

[121] Black, R.E.; Morris, S.S.; Bryce, J. Where and why are 10 millions children dying every year? Lancet, 2003, 361, 2226-2234.

[122] El-Ghannam, A.R. The global problems of child malnutrition and mortality in different world regions. J. Health Soc. Policy, 2003 16, 1-26.

[123] Ferro-Luzzi, A.; James, W.P.T. Adult malnutrition : simple assessment techniques for use in emergencies. Br. J. Nutr., 1996, 75, 3-10.

[124] Waterlow, J.C. Protein-energy malnutrition: the nature and extent of the problem. Clin. Nutr. 1997, 16 (Suppl 1), S3-S9.

[125] de Onis, M.; Monteiro, C.; Akré, J.; Clugston, G. The world magnitude of protein-energy malnutrition: an overview from the WHO global database on child growth. Bull. WHO, 1993, 71, 703-712.

[126] Stephenson, L.S.; Latham, M.C.; Ottesen, E.A. Global malnutrition. Parasitology, 2000, 121, S5-S22.

[127] Khan, N.C.; Tuyen, le D.; Ngoc, T.X.; Duong, P.H.; Khoi, H.H. Reduction in childhood malnutrition in Vietnam from 1990 to 2004. Asia Pac. J. Clin. Nutr., 2007, 16, 274-278.

[128] Faruque, A.S.; Shamsir Ahmed, A.M.; Tahmeed Ahmed.; Munirul M.; Iqbal Hossain, M.; Roy, S.K.; Nurul Alam; Iqbal Kabir; Sack, D.A. Nutrition : Basis for healthy children and mothers in Bangladesh. J. Health Popul. Nutr., 2008, 26, 325-339.

[129] Wang, X.; Wang, Y.; Kang, C. Feeding practices in 105 countries of rural China. Child Care Health Dev., 2005, 31, 417-423. 
[130] Antony, G.M.; Laxmaiah, A. Human development, poverty, health \& nutrition situation in India. Indian J. Med. Res., 2008, 128, 198205.

[131] Kumar, S. South Asia fails to reduce malnutrition burden. Lancet, 2001, 357, 1511.

[132] Ngare, D.K.; Muttunga, J.N. Prevalence of malnutrition in Kenya. East Afr. Med. J., 1999, 76, 376-380.

[133] World Health Organization. Physical status: The use and interpretation of anthropometry. WHO Techn Rep Ser 854; WHO: Geneva, 1995.

[134] Ingenbleek, Y.; De Visscher, M ; De Nayer, P. Measurement of prealbumin as index of protein-calorie malnutrition. Lancet, 1972, ii, 106-109.

[135] Shenkin, A.; Cederblad, G.; Elia, M.; Isaksson, B. International Federation of Clinical Chemistry. Laboratory assessment of protein-energy status. Clin. Chim. Acta, 1996, 253, S5-S59.

[136] Hung, C.J.; Huang, P.C.; Lu, S.C.; Li, Y.H.; Huang, H.B.; Lin, B.F.; Chang, S.J.; Chou, H.F. Plasma homocysteine levels in Taiwanese vegetarians are higher than those of omnivores. J. Nutr., 2002, 132, 152-158.

[137] Yajnik, C.S.; Deshpande, S.S.; Lubree, H.G.; Naik, S.S.; Bhat, D.S.; Uradey, B.S.; Deshpande, J.A.; Rege, S.S.; Refsum, H.; Yudkin, J.S. Vitamin $\mathrm{B}_{12}$ deficiency and hyperhomocysteinemia in rural and urban Indians. J. Assoc. Physicians India, 2006, 54, 775-782.

[138] Benzie, I.F.; Wachtel-Galor, S. Biomarkers in long-term vegetarian diets. Adv. Clin. Chem., 2009, 47, 171-222.

[139] Must, A.; Jacques, P.F.; Rogers, G.; Rosenberg, I.H.; Selhub, J. Serum total homocysteine concentrations in children and adolescents : results from the third National Health and Nutrition Examination Survey (NHANES III). J. Nutr., 2003, 133, 2643-2649.

[140] Rauh, M.; Verwied, S.; Knerr, I.; Dörr, H.G.; Sönnichsen, A.; Koletzko, B. Homocysteine concentrations in a German cohort of 500 individuals: Reference ranges and determinants of plasma levels in healthy children and their parents. Amino Acids, 2001, 20, 409-418.

[141] Abdel, G.A.; Abdullah, S.H.; Kordofani, A.Y. Plasma homocysteine levels in cardiovascular disease, malaria and protein-energy malnutrition in Sudan. East Mediterr. Health J., 2009, 15, 14321439.

[142] Moyano, D.; Vilaseca, M.A.; Artuch, R.; Valls, C.; Lambruschini, N. Plasma total-homocysteinemia in anorexia nervosa. Eur. J. Clin. Nutr., 1998, 52, 172-175.

[143] Gallistl, S.; Sudi, K.M.; Erwa, W.; Aigner, R.; Borkenstein, M. Determinants of homocysteine during weight reduction in obese children and adolescents. Metabolism, 2001, 50, 1220-1223.

[144] Borzon-Chazot, F.; Harthe, C.; Teboul, F.; Labrousse, F.; Gaume, C.; Guadagnino, L.; Claustrat, B.; Berthezène, F.; Moulin, P. Occurrence of hyperhomocysteinemia 1 year after gastroplasty for severe obesity. J. Clin. Endocrinol. Metab., 1999, 84, 541-545.

[145] Sheu, W.H.; Wu, H.S.; Wang, C.W.; Wan, C.J.; Lee, W.J. Elevated plasma homocysteine concentrations after gastroplasty in morbidly obese subjects. Intern. Med., 2001, 40, 584-588.

[146] Faintuch, J.; Matsuda, M.; Cruz, M.E.; Silva, M.M.; Teivelis, M.P.; Garrido, A.B. Jr.; Gama-Rodriguez, J.J. Severe protein-calorie malnutrition after bariatric procedures. Obes. Surg., 2004, 14, 175181.

[147] Chandalia, M.; Abate, N.; Cabo-Chan, A.V. Jr.; Devaraj, S.; Jialal, I.; Grundy, S.M. Hyperhomocysteinemia in Asian Indians living in the United States. J. Clin. Endocrinol. Metab., 2003, 88, 10891095 .
[148] Koebnick, C.; Garcia, A.L.; Dagnelie, P.C.; Strassner, C.; Lindemans, J.; Katz, N.; Leitzmann, C.; Hoffmann, I. Long-term consumption of a raw food diet is associated with favorable serum LDL cholesterol and triglycerides but also with elevated plasma homocysteine and low HDL cholesterol in humans. J. Nutr., 2005, $135,2372-2375$.

[149] Coleman, R. The importance of sulfur as a plant nutrient in world crop production. Soil Sci., 1966, 101, 230-239.

[150] Dijkshoorn, W.; Van Wijk, A.L. The sulphur requirements of plants as evidenced by the sulphur-nitrogen ratio in the organic matter: a review of published data. Plant Soil, 1967, 26, 129-157.

[151] Tisdale, S.L.; Reneau, R.B. Jr.; Platou, J.S. Atlas of Sulfur Deficiency. In: Sulfur in Agriculture; Tabatabai, M.A., Ed.; American Society of Agronomy, Crop Science Society of America, Soil Science Society of America: Madison, 1986; Vol. 27, pp. 295-322.

[152] Jez, J.M. Sulfur: A Missing Link between Soils, Crops, and Nutrition; American Society of Agronomy, Crop Science Society of America, Soil Science Society of America: Madison, 2008.

[153] Beaton, J.D.; White, M. Occurrence and correction of Sdeficiencies in the Asian and Pacific region: a review and update. The Sulphur Institute : Washington D.C., 1997, pp. 31-46.

[154] Khurana, M.P.S.; Sadana, U.S.; Bijay-Singh. Sulfur-Nutrition of Crops in the Indo-Gangetic Plains of South Asia. In: Sulfur: A Missing Link between Soils, Crops, and Nutrition; Jez, J.M., Ed.; American Society of Agronomy, Crop Science Society of America, Soil Science Society of America: Madison, 2008; Vol. 50, pp. 1124.

[155] Surridge, C. Rice cultivation : Feast or famine ? Nature 2004, 432, 814.

[156] Fox, R.L.; Blair, G.J. Plant responses to sulfur in tropical soils. In: Sulfur in Agriculture; Tabatabai, M.A., Ed., American Society of Agronomy, Crop Science Society of America, Soil Science Society of America: Madison, 1986; Vol. 27, pp. 405-434.

[157] Galili, G.; Amir, R.; Hoefgen, R.; Hesse, H. Improving the levels of essential amino acids and sulfur metabolites in plants. Biol. Chem., 2005, 386, 817-831.

[158] Fageria, N.K.; Baligar, V.C.; Jones, C.A. Growth and Mineral Nutrition of Field Crops, Taylor \& Francis: London, 2010.

[159] Kumar, Y.; Das, R.; Garewal, G.; Bali, H.K. High prevalence of hyperhomocysteinemia in young population of North India - a potential risk factor for coronary artery disease? Thromb. Res., 2009, $123,800-802$.

[160] Ghosh, K.; Khare, A.; Shetty, S. Fasting plasma homocysteine levels are increased in young patients with acute myocardial infarction in Western India. Indian Heart J., 2007, 59, 242-245.

[161] Christopher, R.; Nagaraja, D.; Shankar, S.K. Homocysteine and cerebral stroke in developing countries. Curr. Med. Chem., 2007 14, 2393-2401.

[162] Ahmad, U.; Frossard, P.M. Letter to the Editor. Coronary heart diseases in South Asia : Need to redefine risk. Int. J. Cardiol., 2006, 107, 289-290.

[163] Lee, J.; Heng, D.; Chia, K.S.; Chew, S.K.; Tan, B.Y.; Hughes, K. Risk factors and incident coronary heart disease in Chinese, Malay and Asian Indian males : the Singapore Cardiovascular Cohort Study. Int. J. Epidemiol., 2001, 30, 983-988.

[164] Srivastava, R. South Asia's governments exhorted to focus on CVD. Lancet, 2002, 359, 858. 